\title{
Nietzsches 'pile' \\ - Sentenser og ordsprog - sommeren 1883
}

\begin{abstract}
"Hvem ved, om De ikke er kommet alt for tæe på at finde Filoktet på hans ø? Og endog på noget af Filoktets tro: "uden mine pile vil ingen Ilion blive erobret!"”
\end{abstract}

F. Nietzsche i brev til H. von Stein, september 1884

Efter færdiggørelsen af den første bog i det senere firdelte hovedværk $S a$ ledes talte Zarathustra kompilerede F. Nietzsche en mindre samling af aforismer. Samlingen indleder den 308 sider lange notesbog (i kvartformat) Z I 3, og er efter al sandsynlighed udarbejdet efter januar 1883 - altså efter færdiggørelsen af manuskriptet til Således talte Zarathustras første bog - og før værkets anden bog forelå i dens sidste håndskrevne version i juliaugust samme år. I disse mellemliggende måneder opholder Nietzsche sig fortrinsvis i Genova (februar-maj), Rom (maj-juni) og i Sils Maria (juniseptember). Vanskelige og slidsomme måneder efter R. Wagners død i februar, bruddet med P. Rée og L. Andreas-Salomé og med de sædvanlige trakasserier med søsteren Elisabeth - to år senere gift Förster. Notesbogen opbevares i dag i Goethe- und Schiller Archiv i Weimar og er katalogiseret under arkivsignaturen $71 / 137$.

Samlingen af aforismer omfatter 201 sentenser. Alle sirligt nummereret fra 1 til 200 dog på nær en enkelt, som udgør en senere og af Nietzsche tilføjet bemærkning under nummereringen 101. Måske udgør de to sentenser en enkelt aforisme. Samlingens omfang er 52 sider med titelblad. Efter de nummererede aforismer følger en række unummererede sentenser, som afløses af mere udførlige bemærkninger og notater. I notesbogen veksles der mere generelt mellem korte impressionistiske notater, længere tankebevægelser, større gennemarbejdede tekstfragmenter, brevudkast, skitser til forord og opremsende lister af forskellig art. Der optræder eksempelvis flere stikord til og overvejelser over tilrettelæggelsen af den anden bog $\mathrm{i}$ Zarathustra-værket, en større samling af tekstfragmenter, der efterfølgende indgår i kapitlet "Om tarantellerne" i nævnte anden bog og desforuden foreligger der en længere skitse til en Moral for moralister - antageligt det ud- 
kast, som Nietzsche henviser til i et brev til vennen F. Overbeck i midten af august: "(I mellemtiden er skitsen til en "Moral for moralister" blevet færdig.)" Samlingen og udpluk af notesbogen er udgivet i bind 10 i Friedrich Nietzsches Sämtliche Werke. Kritische Studienausgabe.

Samlingen bærer - typisk for Nietzsches skitser i Nachlass - flere titler og i dette tilfælde to. På titelbladet er der anført med stor skrift " 'Ond visdom" / Sentenser og ordsprog / af / Friedrich Nietzsche". Og i nederste venstre hjørne på samme blad og indrammet i en mindre firkant er den anden overvejede titel noteret: "Pile / Sentenser og ordsprog / af / Friedrich Nietzsche”. Herefter følger samlingen på notesbogens venstre sideblade. På første linie nummereringen, på den eller de efterfølgende linier sentensen, herefter følger på en ny linie en ny nummerering, på den eller de efterfølgende linier en ny sentens og så videre. Der er ingen optegnelser på notesbogens højre sideblade i den del, hvor samlingen optræder - i få tilfælde er disse dog inddraget. Eksempelvis er en af siderne blevet anvendt senere $\mathrm{i}$ forbindelse med udarbejdelsen af en passus til et forord til et andet planlagt værk. Størstedelen af samlingens sentenser fremstår som renskrevne og uden tilføjelser, rettelser og overstregninger. Dog forekommer der visse anmærkninger. Manuskriptet bærer tydelig præg af de senere redaktørers arbejde med samlingen. Flere af siderne er overstreget med en diagonal linie fra venstre mod højre og på samlingens højre sideblade er der et større antal redaktionelle henvisninger til bemærkninger i Nietzsches udgivne værker. Her forsøges aforismernes første forekomst identificeret og angivet.

Omtrent halvdelen af samlingens aforismer er repetitioner af tidligere udgivne sentenser i Menneskeligt, alt for menneskeligt, Morgenrode, Spredte tanker og ordsprog, Vandreren og hans skygge og i forste bog af Saledes talte Zarathustra. Rækkefølgen i gengivelsen af flere sentenser peger i retning af, at Nietzsche har skimmet de omtalte tekster igennem og udvalgt de aforismer, han har fundet værd at indføje i samlingen. Det er vanskeligt på entydig vis at pege på et eller to kriterier for udvælgelsen af de forskellige sentenser. Samlingens resterende sentenser er 'nye' og de fleste inddrages efterfølgende under udarbejdelsen af de senere udgivelser, her dog fortrinsvis i forbindelse med arbejdet med den anden, tredje og fjerde bog i Zarathustra-værket. I inddragelsen indføjes sentenserne ofte i Zarathustras taler på en sådan måde, at deres tidligere form af en selvstændig sentens opløses. Nietzsches naturalistiske bestemmelse af mennesket som et dyr med evne for (ofte selvobstruerende) moralske/præskriptive domme - "89. Men- 
nesket er dyret med røde kinder: mennesket er dyret, som ofte har måttet skamme sig." - indføjes således på følgende vis i talen "Om de medlidende" sideløbende med en inddragelse af sentens 110: "Men da siges det bedre således: "Den erkendende går iblandt mennesker som de dyr, de er." Men mennesket selv vil for den erkendende sige: dyret med de røde kinder. Hvordan gik det til? Er det ikke, fordi det for ofte har måttet skamme sig? Åh, mine venner! Sådan taler den erkendende: skam, skam, skam - det er menneskets historie!" En enkelt sentens anvendes to gange, nemlig samlingens parodiske (140) vinkling af det kristne dictum om at "Det er saligere at give end at tage" (Apostlenes Gerninger 21, 35). Først inddrages den i Zarathustras anden bog i "Nattesangen" og genanvendes siden hen i den tredje bogs "Hjemkomsten". Det kan ikke afgøres om flere af de resterende og ikke genanvendte aforismer i samlingen enten blev forkastet af Nietzsche eller eventuelt gemt til senere brug. Så sent som i august-september 1888 inddrages dog to af sentenserne (115 og 164) i det indledende katalog - med de fra samlingens titel velkendte ord - "Ordsprog og pile" (4 og 39) i Afgudernes ragnarok.

Flere af samlingens nye sentenser er set på baggrund af Nietzsches Nachlass 'nye' i svækket forstand, idet flere af dem optræder allerede i en samling på 445 nummererede aforismer, som udarbejdes i sommeren - efteråret 1882, altså før påbegyndelsen af Zarathustra-værkets første bog. Denne omfattende samling bærer tre titler, hvoraf den sidste "' Hinsides godt og ondt." Sentens-bog" jo forekommer velkendt set i forhold til Nietzsches udgivelse i 1886. Ligeledes optræder flere af Nietzsches nye 'pile' i den senere og uden titel kompilerede samling på 273 aforismer fra november 1882 - februar 1883. Disse samlingers forekomst blandt Nietzsches efterladte papirer påkalder sig en vis interesse og har endnu ikke været genstand for en indgående behandling. I flere henseender kan samlingerne betragtes som et fingerpeg om et af de mange metodiske greb, som Nietzsche gør brug af i sine forsøg på at overskue og samle sit materiale til Zarathustras taler. At sentenserne i "Ond visdom" eller Pile er samlet under de to titler kunne dog indikere, at Nietzsche på et tidspunkt overvejede en udgivelse. M. Montinari anfører eksempelvis i forbindelse med samlingens første selvstændige udgivelse i 1975, at samlingen måske udgør en af byggestenene til et planlagt værk, der udelukkende skulle bestå af ordsprogslignende tekster (Montinari 1975: 29). Er dette tilfældet fremstår samlingen som et 'brudstykke' fra en aldrig tilendebragt bog. I en anden sammenhæng er det blevet hævdet af R. Small, at samlingen som så var tiltænkt som Nietzsches svar til vennen eller til den da tidligere ven Rées udgivelse Psychologische Beobachtungen fra 1875 - lige som Moralens genealogi kan betragtes som Nietzsches 
udførlige replik til Rées Der Ursprung der moralischen Empfindungen fra 1877 (Small 2005: 64). Det er rigtigt, at der er et vist sammenfald i tema og i enkelte tilfælde i ordlyden mellem Rées aforismer og nogle af Nietzsches. Men Nietzsches emner og problemstillinger rækker mere vidt end Rées. Dog kan den overvejede titel Pile være et vink fra Nietzsches side om, at samlingens sigte er beslægtet med Rées: At udforske og klarlægge den menneskelige psykes logik og dobbeltheder og derved demaskere psykens talent for (selv)bedrag og hykleriske manerer. Nietzsche skriver i Menneskeligt, alt for menneskeligt (36): 'La Rochefoucauld og de andre franske mestre i sjæleransagelse (hvortil for nylig også en tysker, forfatteren af "Psychologische Beobachtungen", har sluttet sig) ligner skarpskytter, der igen og igen rammer den sorte plet - men i den sorte plet af den menneskelige natur." Titlen Pile peger dog også i andre og måske beslægtede retninger, som påpeget af C.P. Janz (Janz 1978: II, 335). I sommeren - efteråret 1884 noterer Nietzsche eksempelvis: '"'Uden mine pile vil erkendelsens Troja ikke blive erobret" - siger jeg Filoktet". Titlen indgår desforuden året efter i sammenhæng med en skitse til et planlagt værk: "Pile / Tanker om og mod den europæiske sjæl / [...] Pile / Tanker om og mod den tyske sjæl". En sidste og oplagt mulighed for samlingens tilvejebringelse kunne dog også være, at aforismerne for en stund var planlagt som et selvstændigt kapitel til en kommende bog. Set i det lys bør samlingen læses som en blandt de udgivne værkers mange sentens-samlinger; i lighed med den senere "Ordsprog og mellemspil" i Hinsides godt og ondt og den førnævnte i Afgudernes Ragnarok. Titlen "Ond visdom" forekommer ikke i andre tekstsammenhænge, hverken i de efterladte papirer eller i de udgivne bøger.

Ud over de anførte grunde påkalder samlingen sig desforuden en interesse, idet samlingen ifølge Small markerer et brud i anvendelsen af genren, her set $\mathrm{i}$ forhold til Nietzsches brug af samme i de udgivne værker, idet der nu fraviges fra den sædvanlige (og ofte redundante) brug af titler til sentenserne (Small 2005: 64). Denne fravigelse fastholdes generelt betragtet herefter. Endelig påkalder samlingen sig en vis opmærksomhed ved det, at den indeholder flere aforismer, som Nietzsche ikke indarbejdede $\mathrm{i}$ de senere og velkendte udgivelser (eksempelvis 92, 124, 130, 145 og 191). Emnemæssigt spændes der som sagt vidt og langt ud over de psykologiske sonderinger. Der indledes med en kritisk (måske selvironisk) iagttagelse angående meningsdanneres arbejdsmoral og tyngde. Senere gennemspilles Nietzsches velkendte kritiske blik på kristendommen (37 og 128), religion generelt - "91. Tror I, som I siger, på religionens nødvendighed? Vær nu 
ærlige! I tror kun på politiets nødvendighed.” - og hans kritik af moralen (93). Nietzsches omskrivninger, eller som det hedder efter 1886, hans omvurdering af de kristne værdier vinder også indpas i samlingen - "103. Troen gør salig, navnlig troen på os selv." - Nietzsches syn på det akademiske arbejde som en art 'industrivirksomhed' genfindes ligeledes (86) og ligeså hans opposition mod alt, hvad der peger i retning af en egalitær anskuelse - "119. "Menneskene er ikke lige!" - Sådan taler retfærdigheden." - Desforuden rummer samlingen flere prægnante illustrationer og angivelser af Nietzsches erkendelsesteoretiske grundantagelser - "63. Ethvert ord er en fordom.", "76. Hvorfor ser mennesket ikke tingene? Det står sig selv i vejen; det dakker tingene til." - Og de filosofihistoriske præferencer (126) og forkærlighed for kynikeren Diogenes fra Sinope fornægter sig ej heller i denne sammenhæng (62 og 129). Et tilbagevendende tema i samlingen, som varieres ad flere omgange er forholdet mellem mester og discipel - "36. Svenden elsker mesteren på én måde, en mester elsker mesteren på en anden måde.” - Endelig udstilles også i denne samling de velkendte temaer om det enerådende, men ensomme menneskes kvaler og fristelser (191) og om lidelsens uomgængelighed, ligegyldigt hvilken livsførelse der vælges: "35. I ensomheden æder den ensomme sig selv op, i flersomheden bliver han ædt op af de mange. Vælg nu."

Den foreliggende oversættelse af "Ond visdom" / "Pile" følger G. Collis og M. Montinaris tekst i bind 10 (s. 383-400) af Sämtliche Werke. Kritische Studienausgabe. Tak til Goethe- und Schiller Archiv for tilladelse til at arbejde med en kopi af manuskriptet og ikke mindst tak til C. Holten, P. Cripps og to reviewere for berigtigelser og råd i forbindelse med oversættelsen af samlingen.

\section{Litteratur}

Janz, C.P. (1978): Friedrich Nietæssche. Biographie, 3 Bände, München: Carl Hanser Verlag. Montinari, M. (1975): "Nachwort", i F. Nietzsche: Böse Weisheit. Sprüche und Sprüchwörtliches Pfeile, Berlin: Walter de Gruyter.

Nietzsche, F. (1883): Quartheft. Z I 3, Archivsignatur 71/137, Weimar: Goethe- und Schiller Archiv.

Nietzsche, F. (1986): Sämtliche Briefe. Kritische Studienausgabe, 8 Bände, Berlin: Walter de Gruyter.

Nietzsche, F. (1988): Sämtliche Werke. Kritische Studienausgabe, 15 Bände, Berlin: Walter de Gruyter.

Small, R. (2005): Nietæsche and Rée. A Star Friendship, Oxford: Clarendon Press. 